infection of milk in cases where there is tuberculosis in the cow of other parts than the udder are of the utmost importance, and will seriously modify the view taken by health authorities as a general rule. This country is in many respects behindhand in the management of its milk-supply. Steps are being taken both by private individuals and by public bodies in the direction of wiser policy. The report of the Commission will do much to strengthen the hands of those who are working towards the purification' of this indispensable article of diet.

\title{
A CRITICAL IMPRESSION OF THE ANNUAL CONFERENCE OF THE NATIONAL ASSOCIATION FOR THE PREVENTION OF CONSUMPTION.
}

\author{
BY HALLIDAY G. SUTHERLAND, \\ M.D.,
}

Medical Officer to the St. Marylebone Dispensary for the Prevention of . Consumption.

The Annual Conference of the National Association for the Prevention of Consumption was opened at the Caxton Hall, London, on July 19 , by the following gracious message from His Majesty the King:

"As patron of the National Association for the Prevention of Consumption and other forms of Tuberculosis, I congratulate all who will take part in the Annual Conference which assembles to-morrow. I sympathize deeply with the Association's work, so far-reaching in its influence upon the future of the human race. I note with interest the important questions to be dealt with at the Conference, and the names of the eminent authorities by whom the meetings will be conducted and addressed."

At the Annual Meeting following the Conference, a loyal message of thanks was tendered to his Majesty. The Conference was entirely occupied with a discussion of the best ways in which to administer the grants voted in the Budget for dealing with tuberculosis, in accordance with the Chancellor's National Insurance Scheme, the five sessions being divided as follows :

I. Education, i.e., the spread of knowledge about tuberculosis among the community at large, by lectures, literature, exhibitions, etc., and in the school.

2. The Machinery of Detection.-The hospital, the tuberculosis dispensary, municipal and private effort. 
3. Treatment.-The sanatorium, its educational use, home treatment, treatment of the advanced cases.

4. After-care of patients.

5. The Administrative and Financial Aspects of the Bill.-The cost to the community of tuberculosis, the use of existing accommodation.

\section{The Address by Mr. John Burns.}

In these circumstances it was singularly fortunate that Mr. John Burns, President of the Local Government Board, was present to deliver the introductory address. In a statesmanlike speech he covered most of the field, dealing with the various factors which make for the extermination of tuberculosis, indicating their relative importance from the administrative side, and contending that they are all interdependent. It was an extremely sympathetic utterance from a Minister who has mastered the work of his own department, having an excellent knowledge of what is wanted, and, what is more to the point, what he himself wants. The limitation of his speech was that it did not touch the Insurance Bill, and this criticism also applies to some of the subsequent papers. Mr. Burns, as head of the Local Government Board, has given every encouragement to a progressive 'policy on the part of public health authorities. He has already anticipated the provisions of the Insurance Bill clealing with the treatment of tuberculosis. Dispensaries, sanatoria, and hospitals for advanced cases can at this moment be created quite apart from the Insurance Bill, and out of the public funds. The result of this is that so far as provision for treatment is concerned, the insured person will not enjoy any great advantage over the uninsured. It is true that the sick allowance may to some extent make treatment more possible in many cases. Let it not be forgotten, however, that the Insurance Bill does not provide for compulsory treatment, and that while Ios. a week may keep a man in a sanatorium, a grant of $5 \mathrm{~s}$. a week will most certainly not achieve this end. If one credits Mr. Burns with a knowledge of this, it was perhaps not unnatural that he left the Insurance Bill alone. He must further appreciate the fact that as principal officer in the public health service, he is also to be in some statutory relation to the local insurance committees, who apparently are to supervise and report on the work of the former. In such a proposition there is an absolute clisregard of symmetry, and of the principles on which the Local Government Board was established in 1871 .

\section{The Papers Presented.}

The executive of the National Association initiated a new departure at this Conference in devoting most of the time to the reading of 
papers by those who have the right to speak with expert knowledge on the various subjects. This policy was an unqualified success in that every aspect of the tuberculosis campaign was represented, and overlapping, so frequent on such occasions, was reduced to a minimum. Further, as delegates were present from all parts of the kingdom, it was well that they should have had an opportunity of hearing a reasoned and expert presentation of every part of the case.

\section{Educational Communications.}

Professor G. Sims Woodhead, in the introductory paper, advocated the extension of the teaching of hygiene from elementary to secondary schools. Money expended in prevention would be more than repaid by the increased cash value of a healthy community. Under favourable conditions tuberculosis was one of the miost curable of diseases. The educational crusade should be a broad and common-sense one; and those who engaged in it should not be so insistent on a particular method, such as the sanatorium or dispensary. 'There was no universal panacea.

\section{The Rôle of the School.}

Dr. Shrubsall, Assistant School Medical Officer to the London County Council, saicl that school teaching in its earlier stages dealt with the broad lines of personal hygiene, and indirectly touched tuberculosis. The Council's Education Committee had clecided next winter to provide a course of six lectures for teachers on the manner in which they could assist in the anti-tuberculosis campaign.

\section{Tuberculosis Exhibitions and Caravans.}

Sir William Younger spoke on "Tuberculosis Exhibitions and Caravans." The travelling exhibition was welcomed everywhere, and with its accompanying popular lectures to children and adults, should do much good.

\section{The District Nurse and the Health Visitor.}

Mrs. Howard Marsh read a paper on the work of the Cambridge branch of the League for Physical Education and Improvement, and the way in which the conditions under which infants lived could be improved by voluntary effort in the homes.

\section{Propaganda among the Friendly Societies and Trade and other Organizations of the Working Classes.}

Mr. J. Lister Stead, Secretary Ancient Order of Foresters, described the anti-consumption propaganda carried on among friendly societies and trade unions. 
The Machinery of Detection.

The introductory address was given by Dr. R. W. Philip, of Edinburgh. Condemning the medievalism of limiting attention to pronounced cases of phthisis and to the mortality table, he said that medical students should be trained more exactly in physical and bacteriological methods. The method of out-patient departments needed revision. The doctor and nurse should raid the haunts of the bacillus in the patient's home, and hold a critical march past of the household. The results of this system of domiciliary visits from the dispensary were very striking. Compulsory notification was most desirable.

\section{Public Health Measures and the Hospital Out=Patient Department.}

Dr. Niven, of Manchester, indicated that the great mass of tuberculosis was of human and not of bovine origin.

Dr. Cecil Wall, Assistant Physician to the Brompton and London Hospitals, advocated that a more active policy on the part of outpatient departments would be of great value in areas where these exist. Any congestion would be relieved by the Insurance Bill, as they would retain only their consultative function, so far as persons coming under the Insurance Bill were concerned.

\section{The Tuberculosis Dispensary and other Voluntary Efforts.}

Dr. Halliday Sutherland described the work of detection at dispensaries.

Miss Bibby, of St. Pancras, described the working of a voluntary agency. Miss Cowen, of the Jewish Board of Guardians, and Dr. Hope, of Liverpool, also spoke.

\section{Treatment.}

Sir William Osler delivered the introductory address. The community were becoming more and more alive to the necessity of dealing with this insidious clisease in its early stages. Doctors also needed educating. Like the rest of men, they had many sins, and one was carelessness in examination. How many doctors in cases of cough made a practice of always carefully stripping and examining the chest? This carelessness was especially prevalent in that most vicious type of practice which was about to be foisted on us; contract practice às a rule was bad practice.

Dr. Arthur Latham said that while fresh air and plenty of nourishing food were essential, the cardinal factor was a constant and skilled regulation of rest and exercise.

Dr. Jane Walker contended that many consumptives owed their 


\section{THE BRITISH JOURNAL OF TUBERCULOSIS}

condition to underfeeding. Whatever might be best for ordinary people, consumptives should take three square meals a day.

Dr. Marcus Paterson indicated the possibility of educating the working classes.

Dr. J. J. Perkins advocated the educative value of sanatoria, even for cases who could not be permanently benefited.

Dr. J. E. Squire, Senior Physician to Mount Vernon Hospital, clealt with the effects of the Insurance Bill on home treatment. The consumptive who had to be treated at home was not in the least considered in the Insurance Bill. It remained to be seen whether a man would give up his wage of 20 . or 3 os. a week and enter a sanatorium, leaving his family to exist on Ios. a week, or 5 s. after three months. "Sanatorium benefits". under the Bill might well be extended to include some of the requirements for home treatment, such as the loan of a shelter in which he could sleep in the garden or on the roof, or the grant of a few shillings a week to enable him to occupy a separate room.

\section{Open=Air Schools.}

Dr. Ralph P. Williams, of Sheffield, described the working of an open-air recovery school.

Miss McGaw read a paper on Tuberculosis Schools, dealing in detail with the Paddington Tuberculosis School at Kensal House, the first of its kind in London.

\section{Advanced Cases, Segregation, and After=Care of Patients.}

Dr. Maxwell Williamson, Medical Officer of Health for Edinburgh, iliustrated the value of segregation by the fact that in four years following the establishment of a hospital for advanced cases the proportion of deaths from consumption in private houses had fallen from 73 to $5 \mathrm{I}$ per cent.

Mr. C. S. Loch said the Insurance Bill should make provision for after-care, unless this was left to charity, but the Bill would reduce charitable subscriptions.

Dr. H. W. McConnel, of Kelling Sanatorium, said that sanatoria could not possibly maintain their present satisfactory results unless the State-paid sanatoria were worked through the existing sanatorium machinery, and unless all working patients whose work was part of their treatment were freed from the action of the Bill.

\section{The Administrative and Financial Aspects of the Insurance Bill.}

The introductory address was delivered by Dr. W. Leslie Mackenzie, who considered the problem in relation to the housing question. The cost to the community of tuberculosis was dealt with 
in an able and striking address by Mr. Waldorf Astor, M.P. The use of existing accommodation was discussed by Dr. Nathan Raw, who suggested the use of empty fever hospitals and Poor Law institutions for treatment. The general and medical aspects of the National Insurance Bill were dealt with by Mr. Ernest J. Schuster, LL.D., who delivered a most damaging criticism of the Insurance Bill. The Bill did not enable any authority to compel patients to take sanatorium treatment. Further, the scheme was characterized by excessive centralization. In Germany the institutions administering invalidity insurance, though using sanatoria as much as possible, had begun to support voluntary dispensaries, and made loans for the erection of healthy dwellings for workmen and for other preventive purposes. The Bill should provide more definitely for the support of hospitals and district nurses. If it authorized a society to substitute hospital treatment for other benefits, the general health would be improved and the hospitals would secure a good source of income. The funds available for the health committees would probably not go very far ; and such.committees, by majority elective, would not win public confidence as authorities on hygiene. The system of free choice of doctors, apparently agreed on by the Chancellor of the Exchequer and the British Medical Association, was as objectionable as the contract system, both giving the best chance to the worst man, who would curry favour with committees and patients. Some of the classes excluded from the Bill's benefits lived uncler the worst conditions. Having regard to the composition of the health committees, it was very doubtful whether the most suitable cases would be selected for the sanatorium or whether the appropriate treatment would be supplied. The State scheme would be worse than useless unless voluntary effort helped by calling attention to suitable cases supplementing deficient funds, criticizing faulty administration, and enlightening the public as to the advantages of precautions and treatment. In short, the proposed measures regulating the general conditions of public health were of very problematical value.

\section{Voluntary Effort.}

Voluntary agencies and the Bill received consideration, and the chairman, Dr. T. Dyke-Acland, Physician to Brompton Hospital, moved the following resolution: "That, while welcoming the increased facilities for dealing with tuberculosis outlined in the National Insurance Bill, this meeting of the National Association for the Prevention of Consumption desires to place on record its appreciation of the many valuable institutions for treating tuberculous cases which have been organized by voluntary effort, whether they be hospitals, sanatoria, dispensaries, or other organizations. These 


\section{THE BRITISH JOURNAL OF TUBERCULOSIS}

institutions have been pioneers in the fight against consumption, and in the opinion of this meeting have established a special claim for consideration at the hands of those whose duty it will be to administer the provisions of the Bill."

Mr. C. S. Loch, Secretary of the Charity Organization Society, in seconding, said : "The whole treatment of phthisis has altered in the last few years. The sanatorium has been followed by the dispensary for the prevention of consumption. Both movements sprang out of voluntary effort. The dispensary has put a new weapon in the hancls of the medical profession. They can now act largely on preventive lines, and by dealing with contact cases they find also the centre of infection. The National Insurance Bill proposes an expenditure of a million and a half on sanatoria, and though the word 'sanatorium' is used so as to apply to institutions other than institutions for the treatment of phthisis only, still readers of the Bill and of Mr. Lloyd George's speeches must consider that the new sanatoria now proposed to be built are to be chiefly sanatoria for phthisis. The Bill, so far as dispensaries and other similar agencies are concerned, leaves the position obscure. If there are to be more sanatoria, there must be more and better local agencies to utilize and co-operate with sanatoria. These limits-indeed the whole organization of the system-are lacking in the Bill. But however that be, one thing is clear. Our thanks are due to our leaders, to Dr. Philip and many others, lay and medical, men and women, who, working on voluntary lines, have shown us what to do. On the eve of the possible introduction of an entirely new national and obligatory system of insurance against sickness, it is but right and honourable to thank those to whom our debt is great, though the voluntary lines on which they worked may now be superseded-how far we cannot tell." The motion was carried nem. con.

\section{Conclusions.}

There is no question that the Conference was an unqualified success, on which Dr. J. J. Perkins, Hon. Secretary of the National Association, and his co-workers are to be congratulated. The Conference brought out a general, strong, well-weighed opinion that while the Insurance Bill is good in principle it is bad in conception. It is difficult to imagine any other finding on the part of an independent scientific body.

The German Insurance Bill was ten years before the country, and even now there are over two thousand amendments awaiting consolidation into an Insurance Act. It may be objected that the official purpose for which this Conference was called only postulated "a discussion of the best ways in which to administer the grants voted in 
the Budget for dealing with tuberculosis." As these grants, however, can only be administered through the machinery proposed in the Insurance Bill, it is obvious that the findings of the Conference directly apply to that measure.

Although some of the delegates expressed the opinion that more time should have been given for an open discussion, the general feeling was that ample opportunity was granted on the last day of the Conference. After all, discussion can only subserve two purposeselicit new information, or correct the over-accentuation of any one point. Considering the wide range of subjects, and the very representative selection of speakers, there was little danger of the Conference suffering from want of discussion, while on the other hand, the time allowed for papers enabled the delegates to return to their constituencies with the crystallized knowledge gathered from those whose premier interest is in tuberculosis.

The fact of discussion being limited on this occasion was no doubt responsible to some extent for the debate being mostly to the point and of considerable interest. Those delegates who took part had experience in local administration, and were truly in search of knowledge. 